\title{
Pengembangan Media Computer Assisted Instruction Interaktif Dalam Mengoptimalkan Hasil Belajar IPS Siswa Kelas IV
}

\author{
Mohammad Irfan Ferdiansyah ${ }^{1}$, Siti Malikhah Towaf ${ }^{2}$, A. Rosyid Al Atok ${ }^{3}$ \\ ${ }^{1}$ Pendidikan Dasar-Universitas Negeri Malang \\ ${ }^{2}$ Pendidikan IPS-Universitas Negeri Malang \\ ${ }^{3}$ Pendidikan Kewarganegaraan-Universitas Negeri Malang
}

\begin{tabular}{l} 
INFO ARTIKEL \\
\hline Riwayat Artikel: \\
Diterima: $22-11-2018$ \\
Disetujui: $15-01-2019$ \\
\hline
\end{tabular}

Kaa kunci:

interactive media;

computer assisted instruction;

IPS materials,

primary school,

media interaktif,

computer assisted instruction;

Materi IPS;

sekolah dasar

\begin{abstract}
Development research to produce Computer Assisted Instruction interactive media theme "hero" sub-theme "hero is pride" SD IV grade material is valid, interesting, effective, and practical Computer-based learning media can used as alternative in the learning. Media products are developed based the steps of the 4-D development model. The results of validation and trials that have been done, obtained data (a) the results of media validation reached a percentage of $82.5 \%$ with very valid criteria; (b) the results of the media attractiveness test reached a percentage of $95.56 \%$ with very interesting criteria; (c) the practicality test results of students and teachers reached a percentage of $94.8 \%$ with very practical criteria; (d) the results of the effectiveness test that learning outcomes increased by compare the pre-test and post-test results.
\end{abstract}

ABSTRAK

\begin{abstract}
Abstrak: Penelitian pengembangan bertujuan untuk menghasilkan media interaktif Computer Assisted Instruction tema "Pahlawanku" subtema"Pahlawanku Kebangganku" materi IPS kelas IV SD yang valid, menarik, efektif, dan praktis. Media pembelajaran berbasis komputer dapat dijadikan alternatif dalam proses pembelajaran. Produk media dikembangkan berdasarkan langkah model pengembangan 4-D. Hasil validasi dan uji coba yang telah dilakukan, diperoleh data (a) hasil validasi media mencapai persentase $82,5 \%$ dengan kriteria sangat valid; (b) hasil uji kemenarikan media mencapai persentase 95,56\% dengan kriteria sangat menarik; (c) hasil uji kepraktisan siswa dan guru mencapai persentase $94,8 \%$ dengan kriteria sangat praktis; (d) hasil uji efektivitas bahwa hasil belajar lebih optimal dengan membandingkan hasil pre-test dan post-test.
\end{abstract}

\author{
Alamat Korespondensi: \\ Mohammad Irfan Ferdiansyah \\ Pendidikan Dasar \\ Universitas Negeri Malang \\ Jalan Semarang 5 Malang \\ E-mail: irfan.ferdi@yahoo.co.id
}

Secara umum, pendidikan akan menghadapi tantangan yang besar, hal ini tentunya akan berimbas pada siswa dan masyarakat. Fakta di lapangan telah menunjukkan perubahan yang begitu pesat dan hebat, baik dalam lingkup masyarakat umum maupun dalam pergaulan anak. (Kementrian Pendidikan dan Kebudayaan, 2016) mengemukakan bahwa perlunya pembelajaran Ilmu Pengetahuan Sosial mengkaji tentang beberapa tahapan dimulai dari menggali peristiwa, muncullah fakta, menjadi sebuah konsep, dan secara lebih luas menjadi generalisasi yang berkaitan dengan keadaan sosial di masyarakat.

Pembelajaran tematik yang telah dicanangkan oleh pemerintah memberikan konsep yang lebih matang dengan memadukan semua mata pelajaran, baik wajib mapun muatan lokal sehingga pembelajaran semakin kompleks. Namun, sedemikian pula menanamkan pengetahuan sosial merupakan hal yang wajib untuk siswa Sekolah Dasar. Seperti yang diungkapkan (Trianto, 2014) Ilmu Pengetahuan Sosial permasalahan sosial di masyarakat yang saat itu terjadi, penanaman dedikasi mental yang kuat terhadap perubahan segala suatu yang berlangsung, dan terampil menghadapi setiap masalah yang berlangsung setiap saat pada dirinya maupun pada masyarakat. Hal ini dirasa sangat penting dan tepat untuk diterapkannya sebuah inovasi media pembelajaran baru di Sekolah Dasar.

Dalam proses pelaksanaan kurikulum baru baik dari pihak sekolah atau guru masih menemukan banyak kenala. Hasil uji coba yang dilakukan pada tahun pelajaran 2017/2018 ini terdapat kendala dengan masih banyaknya mata pelajaran yang harus di proses menuju kurikulum 2013 sehingga membutuhkan waktu untuk dapat menyesuaikan dengan kurikulum baru. Sehingga dalam pembelajarannya dicoba untuk menggunakan buku tematik siswa dengan harapan pada tahun ajaran baru dapat sepenuhnya menerapkan kurikulum 2013. Pemanfaatan media pembelajaran digunakan oleh guru untuk menjelaskan materi pembelajaran sangat berpengaruh besar terhadap hasil belajar. 
Siswa Sekolah Dasar memiliki usia rata-rata 6-12 tahun dimana seorang anak berada pada tahapan operasional konkret dengan demikian keberadaan media sangat membantu mengoptimalkan pembelajaran IPS di Sekolah Dasar mengingat kembali bahwa pembelajaran IPS banyak ditemukan materi yang lebih bersifat membaca dan menghafal, seperti yang dikemukakan (Piaget, 2010). Dalam tatanan ini siswa hanya dapat berpikir logis dan sistematis tentang benda dan peristiwa yang nyata. (Mursell dan Nasution, 2006) mengungkapkan bahwa masih terdapat pelajaran di sekolah yang tidak memberikan kontribusi baginya dan tidak memberikan hasil secara kompleks karena tidak mengindikasikan perubahan terhadap belajar siswa. (Meolbatak \& Bria, 2016) dalam penelitiannya menjelaskan bahwa proses belajar mengajar yang berbentuk buku dirasa mempersulit siswa dalam menerima informasi secara utuh, sehingga dimunculkan sebuah ide pemikiran untuk mengembangkan media pembelajaran yang interaktif. Imbasnya siswa hanya membaca berulang serta menghafalkan catatan dari buku yang diperoleh saat materi dijelaskan, yang ahirnya bertahan tidak lama dalam ingatan siswa. Permasalahan tersebut sama halnya dengan pembelajaran di kelas IV SDN Marmoyo Jombang, kususnya mata pelajaran IPS. Hasil wawancara dengan sebagian siswa pada bulan Oktober 2017 menunjukkan bahwa siswa kurang tertarik pada mata pelajaran IPS disebabkan oleh materi yang banyak dan menghafal sehingga siswa enggan untuk belajar.

Berdasarkan hasil observasi di SDN Marmoyo Kabuh Jombang pada tanggal 25 Oktober 2017 kegiatan pembelajaran IPS tema 3 tentang "Peduli Terhadap Makhluk Hidup" dilakukan dengan metode ceramah tanpa menggunakan media yang lebih menarik dalam menjelaskan banyak makhluk hidup yang ada di sekitar, serta makhluk hidup yang harus dijaga karena hamper punah populasinya. Siswa hanya mendapat penjelasan materi dengan media gambar yang ada dibuku siswa, sehingga materi yang disampaikan oleh guru kurang optimal. Guru memberikan penjelasan dengan metode yang sangat umum yaitu metode ceramah tanpa didukung oleh media konkret yang mampu mebuat siswa tertaik. Media Pembelajaran yang terbatas berimbas pada kegiatan belajar yang kurang maksimal dan kurang mampu menarik konsentrasi siswa. Pada dasarnya dengan adanya media pembelajaran akan memepermudah penyampaian materi yang diberikan guru kepada siswa. Lebih lanjut, dalam penelitian (Nofiyanto, 2008) yang berjudul 'Membangun Sistem Pembelajaran Pengenalan Bentuk untuk Anak Berbasis Multimedia dan Game Interaktif' dijelaskan bahwa fungsi produk dalam penelitian digunakan untuk mengenalkan bentuk-bentuk dasar menggunakan teknik permainan komputer yang hasilnya sangat berpengaruh terhadap hasil belajar siswa. Software pendidikan dibuat tidak untuk dipakai tugas individu.

Penggunaan media yang kurang optimal dikarenakan berbagai aspek salah satunya terbatasnya waktu yang digunakan untuk mempersiapkan pembuatan media dan sulitnya menemukan media yang sesuai dengan karakteristik siswa. Pembuatan media dapat dilakukan dengan kreasi guru, seperti yang dijelaskan (Marogi, Karlimah, \& Hidayat, 2016) dalam penelitiannya bahwa Multimedia pembelajaran begitu beragam sehingga memberikan variasi pilihan untuk digunakan. Pengguna dapat memilih jenis media apa yang sesuai dan cocok untuk digunakan, baik membeli dari suatu produk atau membuat sendiri sesuai kebutuhan. Kepala Sekolah SDN Marmoyo, Kabuh, Jombang menuturkan pendapat lain dengan terabaikannya media dalam proses pembelajaran yaitu belum optimalnya pemanfaatan komputer, terutama perangkat lunak yang digunakan seperti media berbasis komputer dan aplikasi lainnya yang berhubungan dengan pengoptimalan belajar siswa. Pernyataan tersebut sasuai dengan pendapat (Sanjaya, 2010) mendeskripsikan bahwa di era modern ini sudah banyak terdapat teknologi yang mampu menggantikan fungsi peralatan pada era sebelumnya, seperti opaque, layer OHP, layar lebar dan lain sebagainya

Sekolah Dasar Negeri Marmoyo sudah memiliki bermacam-macam media, namun menurut pendapat yang disampaikan oleh guru saat wawancara, media yang terdapat sudah sering digunakan siswa saat belajar. Oleh kerena itu, siswa merasa bosan dan ketika digunakan media yang sama siswa terlihat kurang antusias untuk belajar sehingga guru merasa media tersebut kurang inovatif dan belum sesuai dengan harapan guru. Dari sudut pandang lain siswa di SDN Marmoyo juga membutuhkan adanya sebuah metode pembelajaran yang baru dan inovatif serta mengacu pada pedoman buku guru dan siswa yang ada sehingga penyampaian materi dapat disampikan dengan baik. Hal tersebut diperkuat dengan penelitian (Priyambodo, 2014) yang menjelaskan bahwa dalam pengamatan penelitian di beberapa sekolah dasar di Yogyakarta, semua pelajaran di sekolah dasar yang didukung dengan fasilitas laboratorium dan teknologi yang memadai dalam sekolah dasar seperti proyektor LCD, layar, dan speaker yang dipasang di setiap kelas. Namun, guru dalam proses belajar mengajar kurang memanfaatkan fasilitas ini untuk aplikasi Multimedia Based Learning.

Berlandaskan pembahasan yang telah dipaparkan dengan belum terdapatnya pengembangan media berbasis program Microsoft Power Point untuk mendukung pembelajaran IPS di Sekolah Dasar, untuk itu peneliti bermaksud mengembangkan sebuah inovasi baru berupa program Power Point yang disajikan berupa aplikasi Computer Assisted Instruction dalam tema V tentang Pahlawanku. Dalam pengembangannya, media ini menyajikan fitur yang sangat kompleks dan dapat secara bebas dipilih sesuai keinginan siswa untuk belajar materi IPS dengan mudah. Harapannya dengan media ini siswa mampu belajar lebih maksimal dan memberikan sajian yang berbeda. Dengan demikian, berlandaskan pemaparan yang terjadi dan beberapa faktor yang positif dengan adanya media pembelajaran. Maka peneliti ingin mengembangkan sebuah media dengan judul "Pengembangan Media Computer Assisted Instruction Interaktif Dalam Pembelajaran IPS Materi Pahlawanku untuk Siswa Kelas IV di SDN Marmoyo Jombang". 


\section{METODE}

Penelitian ini merupakan Research \& Development menghasilkan produk berupa media pembelajaran Computer Assisted Instruction yang interaktif. Menurut pendapat (Effendy, 2008) pada sebuah media pembelajaran dibutuhkan menggunakan model pengembangan yang sesuai dengan sistem pendidikan. Dalam media pembelajaran Computer Assisted Instruction interaktif ini menggunakan model 4-D dikarenakan tahapan model 4-D sistematis dan memiliki tahapan yang tepat dalam pengembangan media pemblajaran. Dengan demikian, pengembangan media pembelajaran Computer Assisted Instruction interaktif dapat mencapai hasil yang maksimal.

Tahapan-tahapan penelitian pengembangan model 4-D (Thiagarajan.S, 1974) terdiri atas empat tahapan, yaitu (a) pendefinisian, (b) design (perancangan), (c) develop (pengembangan), dan (d) disseminate (penyebaran). Pada tahap disseminate membutuhkan waktu yang relatif panjang sehingga tidak dilaksanakan karena pertimbangan peneliti memiliki waktu yang terbatas dan membutuhkan kajian teori dan pengembangan yang lebih mendalam. Oleh sebab itu, penelitian pengembangan ini sampai pada tahap develop.

Kegiatan penelitian pengembangan dimulai dengan tahap pendefinisian (define). Tahap pendefinisian (define) dilakukan untuk menetapkan dan mendefinisikan kebutuhan pembelajaran dengan menganalisis kompetensi dasar, batasan materi, dan indikator yang dilakukan melalui beberapa langkah yaitu (a) analisis awal-akhir yang tujuannya untuk mengetahui masalah dasar yang terjadi dalam pembelajaran, (b) analisis pemelajar (learner analysis) yang bertujuan untuk mengetahui karakteristik siswa, (c) analisis konsep (concept analysis) yang bertujuan untuk memusatkan dan merencanakan pembelajaran dalam menumbuhkan konsep dari materi yang digunakam untuk sarana pencapaian kompetensi, (d) analisis tugas (task analysis), yang untuk menelaah kompetensi inti, kompetensi dasar, dan indikator pembelajaran yang digunakan untuk mengembangkan media pembelajaran dan (e) spesifikasi tujuan pembelajaran (specifying instructional objectives) yang untuk hasil analisis untuk merancang dan menyusun media pembelajaran. Setelah melakukan tahap pendefinisian, kemudian melakukan perencanaan (design). Pemberian inovasi media pada siswa diharapkan mampu memberikan peran penting terhadap peningkatan hasil belajar siswa, seperti yang diungkapkan (Tenri, 2013) penjelasan tentang karakteristik penelitian desain diberikan, bersama dengan argumen untuk adopsi yang lebih luas dari pendekatan ini untuk meningkatkan kualitas dan kegunaan penelitian di komputer dan teknologi lain dalam pendidikan.

(Soeharto, 2003) mengungkapkan bahwa media merupakan berbagai aspek yang terdapat dalam lingkungan belajar siswa, dimana aspek tersebut dapat menambah semangat siswa untuk senantiasa belajar. Tahap perancangan (design) tujuannya untuk merancang prototype media pembelajaran Computer Assisted Instruction interaktif. Langkah yang harus dilakukan ada empat tahapan yaitu (a) menyusun tes pokok acuan (constuction criterion referenced test) yang bertujuan untuk mengidentifikasi target belajar yang harus dicapai oleh siswa melalui tes yang diberikan, (b) pemilihan media, (c) memilih format yang bertujuan untuk mendesain isi media pembelajaran, dan (d) rancangan awal (initial design) yang merupakan tahap untuk memulai merancang media pembelajaran yang dikembangkan. Tahap selanjutnya yaitu tahap pengembangan (develop). Tahap pengembangan (develop) merupakan tahap dalam memperoleh produk yang sudah dilakukan melalui dua tahap yaitu penilaian ahli yang bertujuan untuk mendapat komentar, dan saran tentang pengembangan media. Data hasil validasi berupa data kualitatif dan data kuantitiatif.

Data kualitatif diperoleh dari berbagai komentar dan saran yang diberikan validator ahli dan selanjutnya digunakan untuk memperbaiki produk yang dikembangkan. Data kuantitatif diperoleh dari hasil analisis skor dari lembar validasi yang telah diisi oleh validator ahli untuk menilai komponen kevalidan produk media pembelajaran. Dari hasil uji validasi tersebut, produk direvisi dan kemudian digunakan sebagai bahan pelaksanaan uji coba pada tahap menghasilkan produk final. Uji coba pengembangan (developmental testing). Pada tahap ini tujuannya untuk memperoleh draf final yang sudah direvisi dari masukan para ahli dan data yang diperoleh dari uji coba produk. Dalam proses uji coba produk, diberlakukan dua tahapan yaitu uji coba terhadap kelompok kecil dan uji coba terhadap kelompok besar. Dalam penelitian (Purnamasari, 2016) diungkapkan bahawasanya siswa yang memiliki kemampuan memahami secara sistematis diharapkan dapat mengkomunikasikan kembali dengan harapan pemahaman dapat disampaikan kepada siswa lain. Oleh sebab itu dengan pengembangan media yang telah dijelaskan dalam metode diharapkan siswa dapat belajar dengan optimal dan hasil belajar lebih meningkat.

Terdapat beberapa tahapan pelaksanaan uji coba produk pengembangan buku ajar, di antaranya (a) desain uji coba, (b) subjek uji coba, (c) jenis data, (d) instrumen pengumpulan data, dan (e) teknik analisis data. Desain uji coba memiliki tiga tahapan, yaitu (a) validasi ahli, (b) uji coba kelompok kecil, dan (c) uji coba lapangan. Subjek uji coba ini, yaitu a) validator ahli, b) guru, dan (c) siswa. Jenis data yang digunakan dalam pengembangan ini berbentuk data kualitatif dan kuantitatif, sedangkan instrumen pengumpul data dalam penelitian ini (a) lembar validasi, (b) angket respon siswa dan guru, (c) lembar penilaian, (d) dokumentasi, dan (e) catatan lapangan.

\section{HASIL DAN PEMBAHASAN}

Tahapan pertama setelah menyusun media pembelajaran Computer Assisted Instruction interaktif yaitu dilakukan penilaian oleh validator. Validasi ahli dilakukan untuk memperoleh saran, masukan, dan komentar yang digunakan untuk perbaikan terhadap produk yang dikembangkan. Hasil rekapitulasi uji kevalidan produk media pembelajaran sebesar 87,5\%. Berdasarkan data rekapitulasi kevalidan produk menunjukan kriteria sangat valid sehingga media pembelajaran layak digunakan, tetapi dengan syarat perbaikan yang dilakukan atas dasar saran, komentar, dan masukan yang diperoleh dari uji validasi ahli. 
Adapun saran dan masukan dari ahli materi (a) secara umum sdah menarik, namun lebih dikembangkan soal evaluasi sampai ranah C3 dan C4, (b) tingkat pengecohan pilihan ganda lebih ditingkatkan lagi, dan (c) pengemasan materi lebih ditekankan pada bentuk kepahlawanan. Kemudian masukan dan saran dari ahli desain, yaitu perlu ditambah gambar dan audio tentang pahlawan yang lebih menarik, misal terdapat foto pahlawan yang di klik muncul biografinya dan bentuk perjuangannya.

Setelah melakukan validasi pada semua ahli, tahap selanjutnya dilakukan uji coba kelompok kecil. Uji coba dalam kelompok kecil dilaksanakan untuk mendapatkan data kemenarikan. Subjek uji coba kelompok kecil terdiri atas tujuh orang yang dipilih oleh guru kelas dengan kriteria, dua siswa memiliki intelegensi tinggi, tiga siswa memiliki intelegensi sedang, dan dua siswa memiliki intelegensi rendah. Siswa diminta untuk menggunakan media pembelajaran Computer Assisted Instruction, kemudian mengisi angket yang telah disediakan. Hasil rekapitulasi analisis kemenarikan sebesar 95,56\%. Berdasarkan kriteria kemenarikan, hasil persentase kemenarikan media pembelajaran Computer Assisted Instruction yang dikembangkan memperoleh kriteria sangat menarik. Dalam penelitian (Galvis, 2011) yang berjudul "A Comparison of Computer-Assisted Instruction and Traditional Classroom Lecture to Introduce the Occupational Adaptation Theory" menjelaskan bahwa semua peserta dalam penelitian ini meningkatkan pengetahuan mereka tentang teori Adaptasi Okupasi, namun peserta dalam kelompok instruksi yang dibantu komputer memperoleh lebih banyak pengetahuan. Adapun kritik dan saran, yaitu (a) merasa senang belajar menggunakan komputer, (b) di lain waktu ingin belajar dengan menggunakan media yang menyenangkan lagi. Berdasarkan kritik dan saran dilakukan evaluasi untuk dapat menggunakan media pembelajaran dilain waktu. Media pembelajaran Computer Assisted Instruction interaktif yang sudah diperbaiki kemudian dapat diterapkan untuk penguji coba lapangan.

Uji coba lapangan diterapkan sebagai sarana melihat kepraktisan media pembelajaran saat digunakan dalam proses belajar. Subjek uji coba lapangan ini yaitu siswa dan guru dengan menggunakan angket respon siswa dan guru. Rata-rata hasil persentase uji kepraktisan sebesar 94,8\%. Ditinjau dari (Sa'dun, 2015) bahwa persentase tersebut menunjukkan kepraktisan penggunaan media pembelajaran Computer Assisted Instruction interaktif berada pada kriteria sangat praktis untuk digunakan dalam kegiatan pembelajaran. Adapun tanggapan yang dituliskan siswa dalam angket, yaitu (a) merasa senang belajar menggunakan komputer, (b) di lain waktu ingin belajar dengan menggunakan media yang menyenangkan lagi. Sementara itu, tanggapan dari guru yaitu pembelajaran media Computer Assisted Instruction mudah dipahami oleh siswa, namun lebih disesuaikan dengan kondisi siswa yang masih senang bermain sehingga konsep kuis lebih menarik.

Data keefektifan diperoleh berdasarkan hasil belajar yang diperoleh siswa dengan melakukan sebuah tes, yaitu pre-test dan post-test. Perbedaan nilai yang dihasilkan saat pre-test dan post-test mencerminkan bahwa siswa mengalami peningkatan rata-rata hasil belajar, dari 61.67 menjadi 85.24 setelah menggunakan media pembelajaran Computer Assisted Instruction interaktif. Hasil pre-test yang menunjukkan presentasi 47,62\% ketuntasan hasil belajar sangat berbeda dengan hasil post-test yang menunjukkan persentase ketuntassan sebesar 90,48\%. Jadi, dapat disimpulkan bahwa menggunakan media pembelajaran Computer Assisted Instruction dapat meningkatkan hasil belajar siswa.

Hasil observasi menunjukkan bahwa media yang digunakan guru masih berbentuk konvensional atau kurang modern. Hal tersebut membuktikan bahwa dengan adanya media yaang konvensional siswa masih semangat belajar meskipun hasil belajar kurang maksimal. Dalam penelitian (Malik, 2012) menjelaskan bahwa adanya media membantu dalam pemecahan masalah dengan cara belajar dengan melakukan, memahami konsep abstrak, menyediakan akses yang ditingkatkan untuk guru dan siswa di lokasi terpencil, memfasilitasi pembelajaran individual dan kooperatif, membantu dalam manajemen dan administrasi kegiatan kelas dan konten pembelajaran, dan mensimulasikan masalah kehidupan nyata penanganan lingkungan. Untuk meningkatkan kualitas pembelajaran di sekolah, hendaklah guru menggunakan media pembelajaran yang inovatif demi kelancaran dalam menyampiakan materi dengan sifat semu menjadi nyata. Pengembangan media pembelajaran merupakan langkah strategis yang dapat dilakukan guru dalam menunjang dan mengoptimalkan hasil belajar siswa, dalam artian mengubah konsep belajar yang lama menjadi konsep yang baru. Media pembelajaran yang dikembangkan adalah media pembelajaran Computer Assisted Instruction, dimana media ini dapat diaplikasikan kepada siswa ataupun guru untuk memaksimalkan hasil belajar. Hasil analisis data dapat disimpulkan media pembelajaran Computer Assisted Instruction memenuhi kriteria valid, menarik, praktis, dan efektif. Meskipun demikian, terdapat komponen dalam produk media pembelajaran yang harus direvisi guna kesempurnaan sebuah media. media pembelajaran Computer Assisted Instruction interaktif telah divalidasi oleh ahli materi, dan ahli media. Media pembelajaran telah melalui tahapan revisi sesuai saran, dan masukan dari validator sehingga media pembelajaran Computer Assisted Instruction interaktif dapat digunakan dengan adanya revisi.

Aspek kemenarikan memengaruhi minat siswa dalam belajar. Media pembelajaran Computer Assisted Instruction disertai dengan foto pahlawan, video bentuk perjuangan dan soal evaluasi yang konkret sesuai dengan lingkungan tempat tinggal siswa. Aspek kepraktisan yaitu kesesuaian, keakuratan materi, serta kemudahan penggunaan media pembelajaran Computer Assisted Instruction dalam pembelajaran. Hal ini sesuai dengan pendapat (Miarso, 2009) bahwa media juga berfungsi untuk mempermudah dan memperjelas konsep belajar yang bersifat abstrak dan sangat kompleks menjadi lebih nyata untuk diphami. Sehingga dengan adanya media kemampuan siswa untuk menerima dan menyerap materi pembelajaran akan semakin tinggi. Sependapat dengan hal tersebut (McKenzie, 2005) dalam karangan bukunya "Multiple Intelligences and Instructional Technology" yang menjelaskan bahwa, peran penting media dalam proses pembelajaran nantinya akan menunjukkan keberhasilan dan kualitas belajar. Dalam pembahasan ini dijelaskan bahwa media mempunyai beberapa aspek yang berpengaruh dalam proses belajar. Dari hasil penjelasan di atas dapat dipersempit dengan menyimpulkan bahwa produk yang dikemas dapat difungsikan sebagai salah satu referensi dalam proses belajar dengan pengategorian sangat praktis. 
Keefektifan media pembelajaran merupakan ketepatan ketercapaian tujuan pembelajaran yang telah ditetapkan. Keefektifan media pembelajaran ini didukung dengan peningkatan pemahaman siswa terhadap tema "Pahlawanku" subtema "Pahlawanku Kebangganku". Media pembelajaran Computer Assisted Instruction telah memenuhi aspek valid, menarik, dan praktis, kemudian diuji coba efektivitasnya yang dilakukan di kelas IV SDN Marmoyo, Kabuh Jombang. Hasil efektivitas dari perbandingan hasil yang telah dicapai oleh siswa memiliki rata-rata pre-test dan post-test setelah siswa menggunakan media pembelajaran Computer Assisted Instruction sebesar 61,67 dan 85,25. Hasil pre-test yang menunjukkan persentase 47,62\% ketuntasan hasil belajar sangat berbeda dengan hasil post-test yang menunjukkan persentase ketuntasan sebesar 90,48\%. Dari pemaparan data yang diperoleh, dapat ditarik simpulan bahwa pengemasan pembelajaran dengan media Computer Assisted Instruction interaktif yang dikembangkan oleh peneliti dikategorikan efektif yang selanjutnya dapat difungsikan sebagai media penunjang di setiap proses pembelajaran di sekolah.

\section{SIMPULAN}

Penelitian dan pengembangan ini menghasilkan produk berupa media pembelajaran Computer Assisted Instruction. Media yang dikembangkan berdasarkan model pengembangan 4-D. Perolehan nilai angket ahli materi serta ahli media yang dilakukan oleh validator, dilanjutkan dengan mengujikan pada kelompok kecil dan kelompok lapangan menunjukkan bahwa media pembelajaran memenuhi kriteria valid, menarik, praktis, dan efektif serta dapat diterapkan pada kegiatan pembelajaran. Penggunaan media pembelajaran ini sangat efektif digunakan oleh siswa, dibuktikan dengan adanya peningkatan signifikan hasil belajar siswa. Penelitian tersebut sama halnya dengan penelitian (Ziden, 2013) yang membuktikan bahwa dengan penggunaan media komputer berupa simulasi, hasil belajar siswa lebih dari pada siswa yang melakukan pekerjaan praktis. Skor retensi siswa dalam simulasi komputer juga lebih tinggi daripada siswa dalam pekerjaan praktis. Dengan demikian, hasil belajar yang diperoleh siswa dapat optimal dan sesuai dengan harapan guru, orangtua, ataupun pihak sekolah.

Sebaiknya media pembelajaran yang dihasilkan dapat disajikan dalam bentuk lainya, misalnya mengembangkan media pembelajaran dalam bentuk software yang dapat digunakan di smartphone atau multimedia interaktif yang disesuaikan dengan karakteristik siswa sehingga dapat lebih ekonomis dari segi biaya pembuatan media pembelajaran serta keadaan dan fasilitas yang dimiliki sekolah.

\section{DAFTAR RUJUKAN}

Effendy, O. U. (2008). Ilmu Komunikasi, Teori \& Praktik. Bandung: PT. Remaja Rosdakarya.

Galvis, A. T. (2011). A Comparison of Computer-Assisted Instruction and Traditional Classroom Lecture to Introduce the Occupational Adaptation Theory. Internet Journal of Allied Health Sciences \& Practice, 9, 1-11. Retrieved from internalpdf://75.215.119.197/Galvis.pdf\%5Cnhttp://search.ebscohost.com/login.aspx?direct=true\&db=cin20\&AN=2011234589\& site $=$ ehost-live

J. Mursell., \& Nasution. (2006). Mengajar dengan Sukses. Jakarta: Bumi Aksara.

Kementrian Pendidikan dan Kebudayaan. (2016). Panduan Teknis Pembelajaran dan Penilaian di Sekolah Dasar. Jakarta: Kementrian Pendidikan dan Kebudayaan.

Malik, S. (2012). Use of Multimedia as a New Educational Technology Tool-A Study. International Journal of Information and Education Technology, 2(5), 468-471. https://doi.org/10.7763/IJIET.2012.V2.181

Marogi, A., Karlimah., \& Hidayat, S. (2016). Pengembangan Multimedia Pembelajaran Interaktif Berbasis Flash Model Simulasi pada Materi Pengenalan Konsep Bilangan Bulat. PEDADIDAKTIKA: Jurnal Ilmiah Pendidikan Guru Sekolah Dasar, 3(2), 292-302.

McKenzie, W. (2005). Multiple Intelligences and Instructional Technology. Washington: International Society for Technology in Education.

Meolbatak, E. M., \& Bria, Y. P. (2016). Penerapan Model Multimedia sebagai Media Pembelajaran Alternatif untuk Meningkatkan Self Motivated Learning dan Self Regulated Learning. Media Teknika: Jurnal Teknologi, 11(2), 83-90.

Miarso, Y. (2009). Menyemai Benih Teknologi Pendidikan. Jakarta: Kencana.

Nofiyanto, F. (2008). Membangun Sistem Pembelajaran Pengenalan Bentuk untuk Anak Berbasis Multimedia dan Game Interaktif. Jurnal Informatika, 2(1), 23-32.

Piaget, J. (2010). Psikologi Anak. Yogyakarta: Pustaka Pelajar.

Priyambodo, E. (2014). The Effect of Multimedia Based Learning (MBL) in Chemistry Teaching and Learning on Students' Self- Regulated Learning (SRL). Journal of Education and Learning, 8(4), 363-367. https://doi.org/10.11591/edulearn.v8i4.384

Purnamasari, S. (2016). Penggunaan Multimedia Interaktif terhadap Peningkatan Kemampuan Pemahaman dan komunikasi Matematis serta Kemandirian Belajar Siswa. Jurnal Pendidikan Dasar, 8(2), 178-185. https://doi.org/10.17509/eh.v8i2.5140

Sa’dun, A. (2015). Instrumen Perangkat Pembelajaran. Bandung: PT. Remaja Rosdakarya.

Sanjaya, W. (2010). Strategi Pembelajaran Berorientasi Standar Proses Pendidikan. Jakarta: Prenada Media Group. 
28 Jurnal Pendidikan, Vol. 4, No. 1, Bln Januari, Thn 2019, Hal 23-28

Soeharto, K. (2003). Teknologi Pembelajaran (Pendekatan Sistem, Konsepsi dan Model, SAP, Evaluasi, Sumber Belajar Media). Surabaya: Surabaya Intelectual Club.

Tenri, A. (2013). The Implementation of Multimedia Learning Materials in Teaching English Speaking Skills. International Journal of English Language Education, 1(3), 293. https://doi.org/10.5296/ijele.v1i3.4153

Thiagarajan.S. (1974). Instructional Development for Training Teachers of Exceptional Children. Bloomington: Indian University.

Trianto. (2014). Mendesain Model Pembelajaran Inovatif, Progesif, dan Kontekstual. Jakarta: Prenada Media Group.

Ziden, A. A. (2013). The Effectiveness of Web-Based Multimedia Applications Simulation in Teaching and Learning. International Journal of Instruction, 6(2), 211-222. https://doi.org/10.12973/iji.2016.9115a 